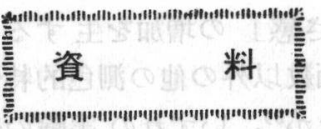

\title{
中国建築に見る採光とその意匠
}

\author{
終身会員 東宮 伝*
}

昭和57年10月, 日本照明委員会 (JCIE) の学術交流訪中 団に参加, 北京, 杭州, 上海を旅行した折のこれら各地の 中国の古い建築物や庭園について，その建物などの採光の 手法やその意匠について資料としてまとめ報告する.

\section{1. 北京・故宮の建築}

北京の故宮は, 明, 清朝の 2 代にわたる王宮であって, からては紫禁城と呼ばれた. 1420年に完成されたもので, 中国に現存する中世建築の中でも最大の規模を持ら, 最も 完全な姿をとどめている宮殿建築群である.

故宮は高さ $10 \mathrm{~m}$ の城壁によって囲まれ，南北 $960 \mathrm{~m}$, 東西 $750 \mathrm{~m}$, 宮殿や楼閣は 60 余, 部屋数は 9,000 にも上る といわれ，見学には少なくとも $2 \sim 3$ 日は必要とのこと， これら建物を 2 時間程度で見学することは不可能であった が，北側の神武門より南側の午門まで, 南北縦に主だった 建物を足早に見学, 写真を撮る. 特に建物の外観の屋根, 室内の天井, 採光空の造形, 室内の灯具, 城内の屋外灯な どに興味を持って見学する.

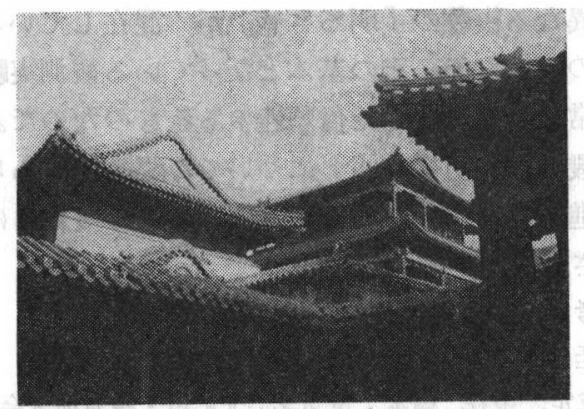

図 1 故宮・閣音啺の屋根がわらの琉璃

図 1 は，閣音暢の何層にも重なり合った屋根の美しさ で屋根がわらの琉璃の造形が興味深い. 特に屋根せん端に 並ぶ仙人と走獣群はほほ古ましく, 中国建築の屋根意匠に ロマンを感ずる.この琉璃の走獣群は文献によれば，それ ぞれ獣名がついている (図 2 参照).

中心的な大和殿，中和殿，保和殿など主だった宮殿の天 井は格天井で彩色も美しく, 天井中心には装飾天井（藻

† Lighting and Light Design as Adopted in Chinese Architecture

* 诛東宮照明設計事務所

Tsutae Tomiya

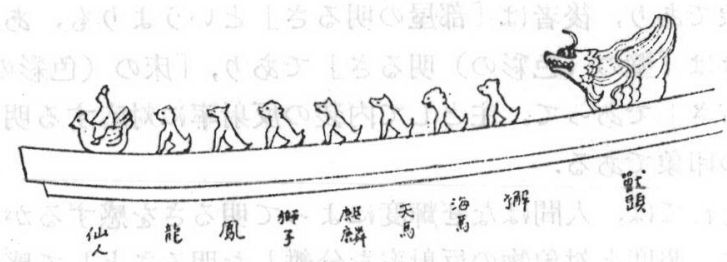

図 2 琉璃の仙人と走獣 (スケッチ)

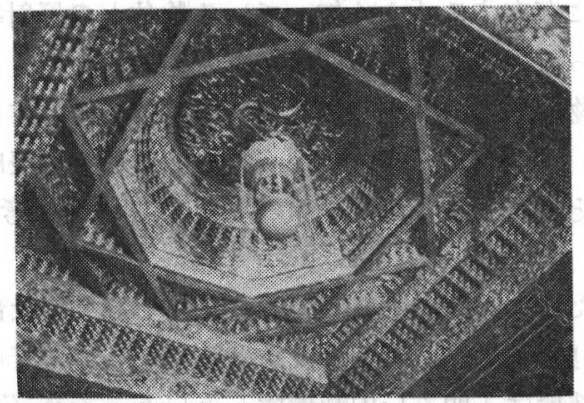

図 3 大和殿の装飾天井

井）が作られ, 図 3 に示すように, 彫刻装飾は黄金色に 輝やき豪華の限りを極めている.

明，清時代の装飾天井は，この時代の中国の室内空間の 装飾工芸の高度な技巧を顕著に表わしている. 形には方形 天井，八角形天井，円形天井などの形式が見られる，装飾 天井中央には，玉をつり下げデザインされたランタン式灯 具がつり下げられて括り, 会や式典などの義式には点灯さ れたものであろら。装飾天井の彫刻模様が浮き彫りに輝や き, 厳かに宮殿内を一層豪華な雾囲気に表現したのであろ $\zeta$.

宮殿内中央には，図４亿示すように宝座（王座）が置 かれ, 宝座は建物の主要な位置を占め, 必す゚台座やつい立

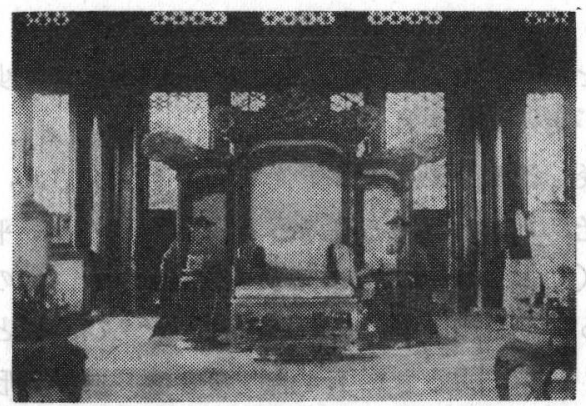

図 4 宮殿の宝座 (王座) と家具配置 
てなどを合わせて配置する，その側に配置される宮灯（宮 廷行灯）や香炉などの陳列品もまた対称型の配置になって いる，そしてほぼ中央に装飾天井があり，昼間は側空の格 子空「欄空」からの光を受けて,くぼんだ装飾天井内が受 光皿効果となって，黄金色に王座の天井が神秘的に神々し く輝やく.これらの建物の採光の格子空の意匠は, 図 $\mathbf{5}$ のように, 1 枚の厚板に切り拔かれた幾何学的な花柄文様 の格子空である. 自然光の直射光と反射光を柔らかくコン トロールして殿内に引き入れる.

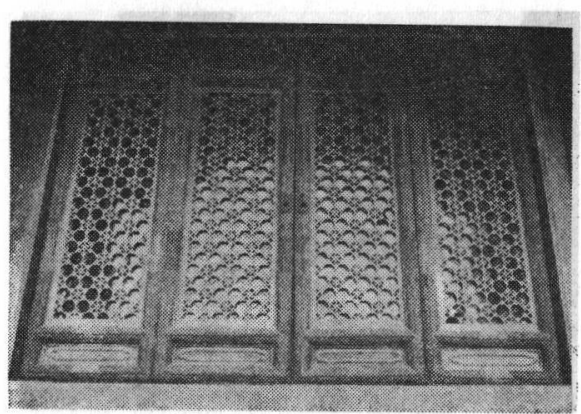

图 5 格子空

また，故宮内の養心殿は皇帝の家族の住まいであったと され，明，清時代の宮殿内の住まいの家具調度品の配置な どを見学することができる.

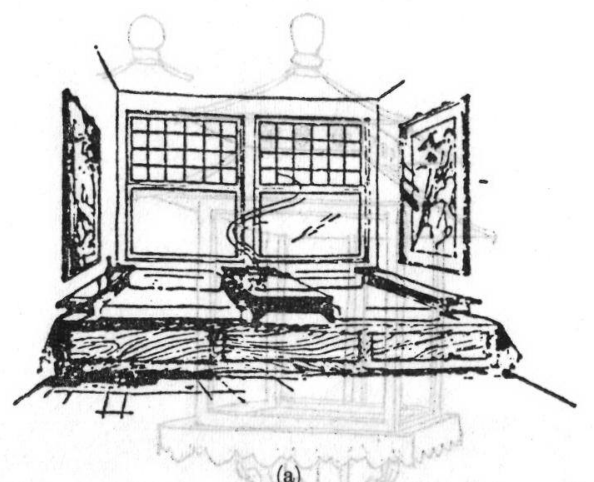

(a)

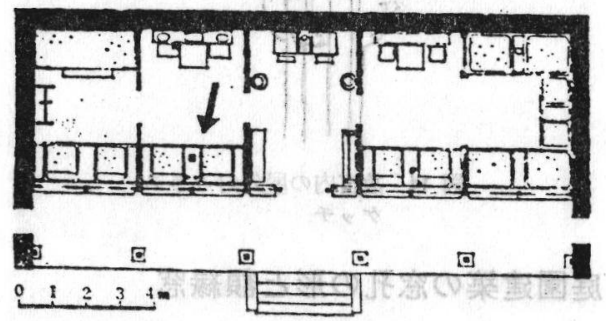

中 庭

(b)

図 6 故宮・盖心殿の 1 階の平面配置困 図(a)は, 図(b)の矢印方向より 見た室内スケッチである・炕牀 （オンドル台）を置き，その両 側に対称的に椅（椅子）と茶几 (茶飲み小テーブル)を置く〕。

図 6 は, 養心殿の一部の平面家具配置図である! 文献 によれば，家具の配置には一定の手法があり，その主要な ものに二つの種類がある. 第一は対称的な配置で政り，第 二は家具がセットをなすもので，対を基本とする。

図 7 は, 養心殿内の居間の対称配置の対の家具であ

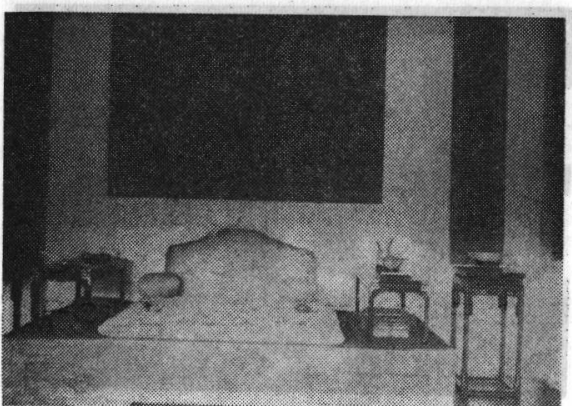

図 7 養心殿内居間の対称配置の家具

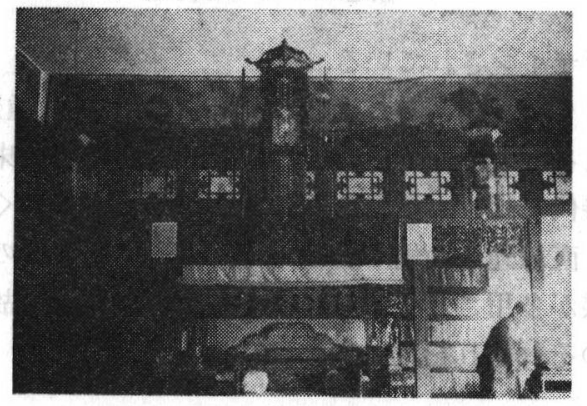

図 8 養心殿内の応接間大広間

る.図 8 は応接用大広間（花庁）である. 中央次の間 は王座があり，写真右空側には，炕牀（オンドル台）が置 かれ，その上に対称的に椅（椅子）と茶艺（茶卓）が置か れている.

室内の照明は, 天井四隅に同形のランタンが 4 灯つり下 げられ，中央にいらだん大きく装飾的なランタンがつり下 げられ，大広間の照明が行なわれるよらになっている，清 の西太后の別荘として作られた頣和園の建物の各室の照明 も, 天井に 4 箇所にハンガーを埋め込み, これにランタン をつり下げるようになっており, 当時の上流階級の住まい の照明は 1 室 4 〜 箇所のランタンによる照明であったよ らである(図 9).

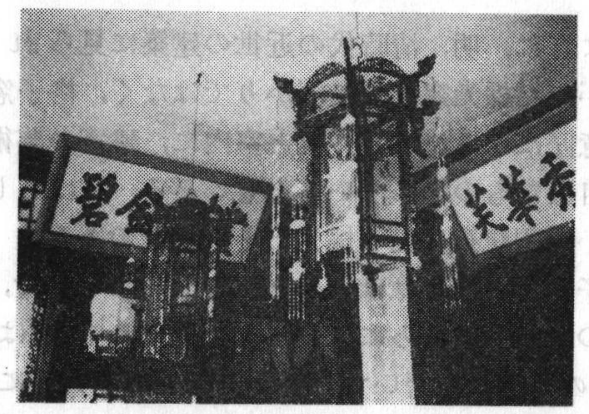

図 9 頋和園の 1 室 4 灯のランタンの 照明

昼間は図 6 に示すよらな，上下段に分かれた格子空より 採光するように考えられている。明かるい空側のオンドル 台の上の椅子に座り, 茶を飲みながら談らんしたり読書し たり，のどかな生活がうかがえる.

図10 は養心殿の空を内側より見たものである.下段の 空に草花の刺しゅうをした絹地のカーテンを使用してい る.その窓格子の意匠は上段は正方形の格子で, 下段は額 


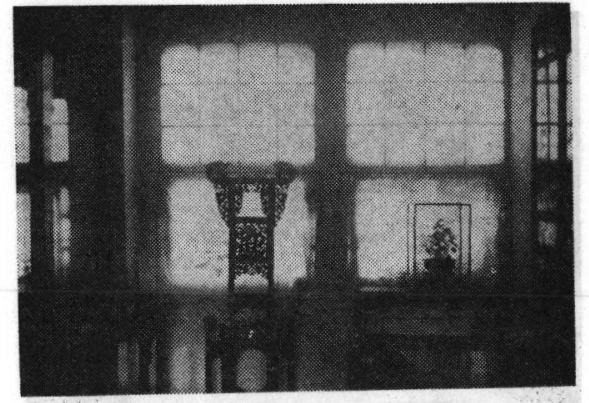

図 10 養心殿内より見た空格子 （下段に草花の刺しゅら 絹地のカーテンを使用)

縁空にデザインされている.

このように, 故宮内の建物の空格子は文様の種類は多 く，それぞれの建物でその文様意匠が異なり，興味深い。 明, 清時代には，この空格子の種類はきわめて多く，その 種類は，直線連子の規則的な文様，連子空は各種の組み合 わせ文様が多用されている，筆者スケッチによる故宮内の 格子空のそれぞれを図 11 に示す。
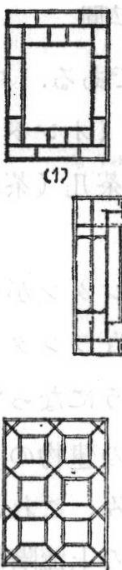

(6)
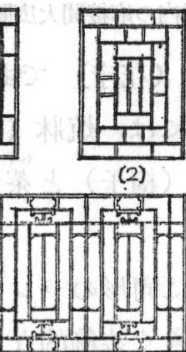

(4)

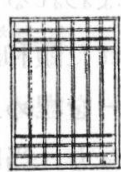

(7)

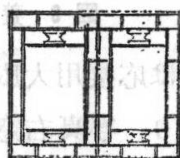

(3)

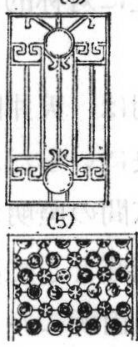

(8)
図 11 故宮の建物の空格子文様 図例

このように，明，清時代の近世の建築に見られるよう に，空がただ採光空としてばかりではなく，格子空文様の 変化の意匠による建物の外観と室内に，建築の芸術的効果 をより自由なものにしているともいえる.すばらしくもま た楽しい中国建築に見る採光とその意匠である.

空格子には初期にはほとんど紙を貼ったもので, 絹を貼 ったものもあり,さらにやや密な空格子の中には, 明瓦 （半透明のかき殼を磨いて薄く仕上げ，空や天井に取り付 ケて採光に用いるもの）をはめ込んで採光させるものもい くつかあった．ガラスは清代中期以降使用されることが多 くなった.

また，故宮内の屋外の照明については，宮殿のまわりの 灯ろらなどについて調査したが，あまりその種類を見るこ とができなかった．ここに 2 種について紹介する.

図 12 に示すような，大和殿の前に対で配された石に彫 刻をほどこした豪華で立派な石灯ろらがあった。』い ：図 13 は，養心殿門の両側に対に配置された灯ろ与式屋

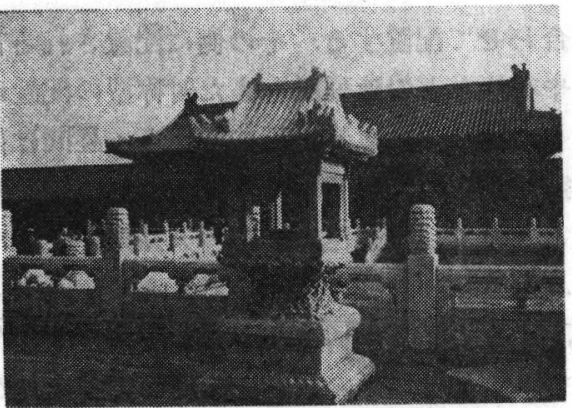

図 12 大和殿前の石灯万弓

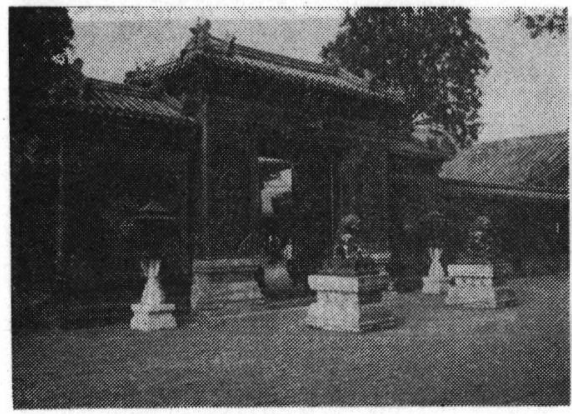

図 13 養心殿前の対の灯ろら

外灯である. 石の台, 柱座の上に青銅製のランタン式灯ろ らが置かれ，柱頭飾りの意匠が図 14 のよらに対になっ ている.

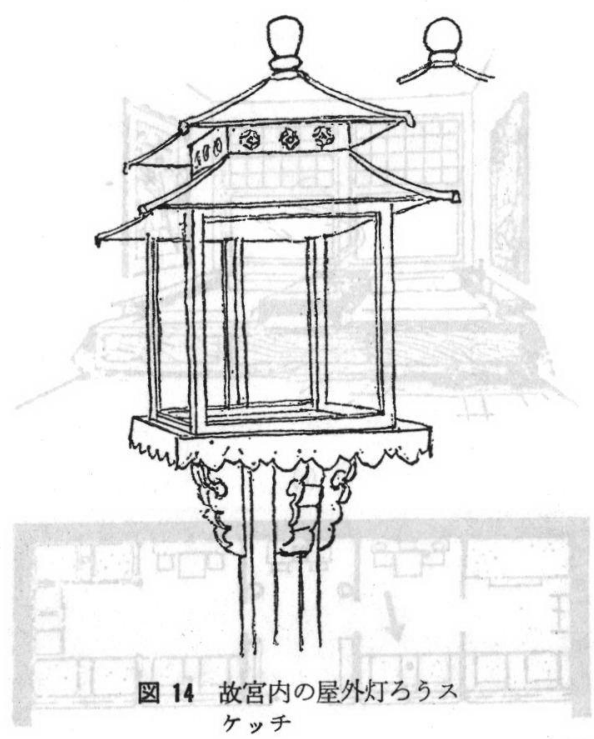

\section{2. 庭園建築の空孔の形と額緑空}

空格子の空孔の形状は四角, 長方形が一般的である.こ のほか中国では，空孔をさまざまな形式に図案化し，特に 庭園などにおいてはきわめて重要な装飾としても，その空 の形状を円形, 五角, 六角, 八角形, 桃実形, 梅花形, 扇 形など，さまざまな形式の空孔にデザインしていることは 興味深い。

図 15 は，北京の願和園の昆明湖に面する建物の空の形 である.この形式は文献によれば什錦灯空といい, 白し っくい壁に桃実形，五角形などさまざまな形式の窓孔をく り抜き，そこにガラスをはめたもので，夜になると火をと もし, 水面にのぞむ壁の火が水面にその形を映する. 対岸 


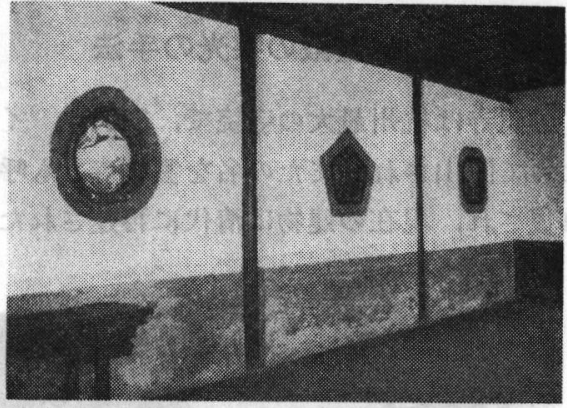

図 15 頋和園の什錦灯空

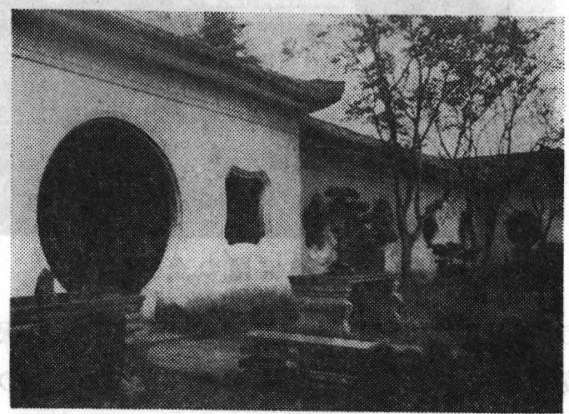

図 16 杭州植物園の建物の空

や舟で遊ぶ人々に非常に感動的な効果が生み出される.

また図 16 は, 杭州の植物園の建物で空の形が円形, 梅花形, 八角形などさまざまな形の空孔がくり抜かれ，そ の空孔の枠が二重，三重に縁どられている．筆者にとって も初めて見るさまざまの空孔形式を有する建物である. 文 献によれば，中国南方の庭園に見られ，透かし空（漏空） という. 種々な形式図案に造られた空が建物の内外観共に 庭園に打ける重要な装飾ともなっている. 図 17 は梅花形 の空で, 室内の空際にも盆栽を置き, 内外からも借景を楽 しむように考えられており，非常に興味深い。

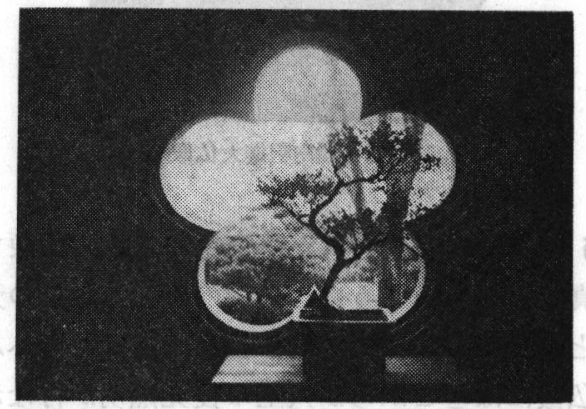

図 17 梅花形の空

空の開閉については, 空孔の内側に 2 枚開きのガラス格 子戸によって開閉されるようになっている.

額縁形式の空は, 名のように空の枠の内側に額緣のよう に幾何学的な文様をはめ込んだ空であって, 採光空と同じ に屋外の風景を, その額縁内に借景する興味ある効果を有 する空である.

文献によれば庭園や住宅によく用いられて, 清朝末期に ガラスが広く使われるよらになってからは, 額縁の中にガ ラスをはめ込むものが多くなった. そのためこの形式の文 様は急速に発展し，文様の種類も非常に多くなった.

図 18 は, 杭州の西湖の湖畔に建っている建物の額縁空

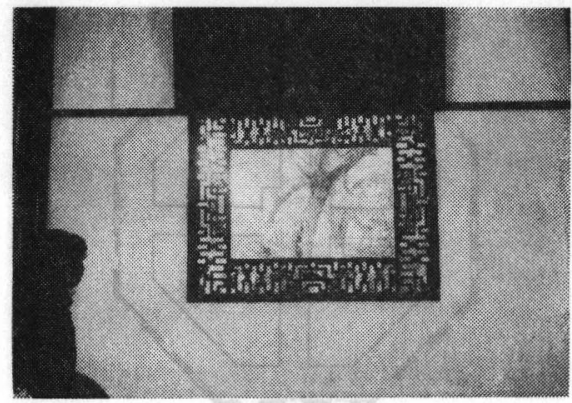

図 18 額縁空の借景の眺め

である. 室内から額縁空を通して眺める屋外の風景は, 本 物の額縁にはめ込まれた絵より以上に,すばらしい借景の 美しい色彩と光と動きそして風音をも加えた自然の眺め に感動する.

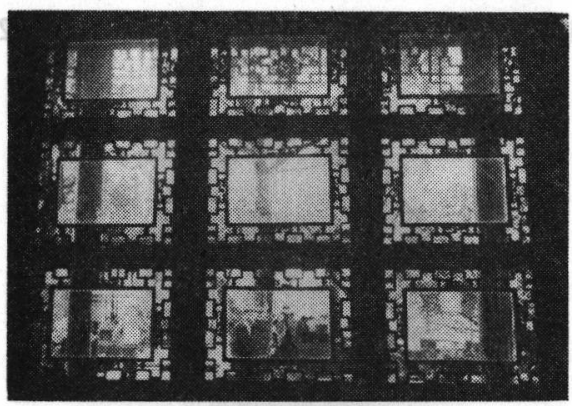

図 19 九等分の額縁空

図 19 は, 同じ建物の前面の大きな空で，九等分された 額縁のそれぞれに屋外の景色が映る. 室内も採光効果で非 常に明るく屋外との隔たりを感じさせない、これもまたす ばらしい中国建築に見る採光とその意匠である.

\section{3. 六和塔の採光}

杭州の銭塘江北岸に建っている高さ $65 \mathrm{~m}$ の塔である. 今から約 1,000 年前 970 年, 宋の時代に町を高潮から守る ための物見の荅として建てられ，灯台の役目も果たしてい た. その後何度か再建, 修復された.

外観は図 20 に示すよらに八角層であって, 内部は7 階，ら施階段を登れば塔の外側を囲む回廊から眼下に銭塘 江と銭塘江大鉄橋が見わたせる。

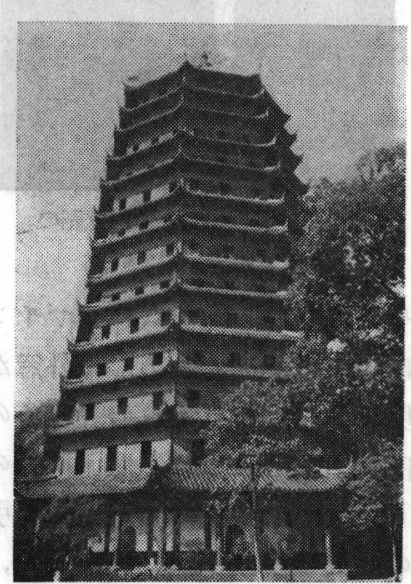

図 20 杭州・六角塔の全景 


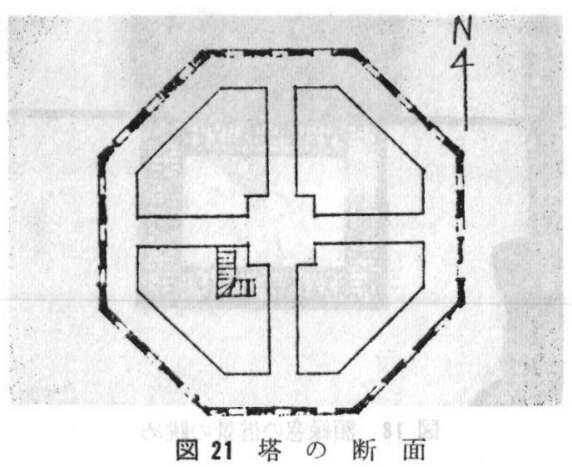

荅の断面は図 21 のよらに, 荅の回廊の各辺に空が三 つずつあって，荅の中央には天井に龍の描かれた四角い部 屋があり，それに通ずる廊下は白しっくいで仕上げられ， 腰部には黒色でそれぞれ変わたっ文様がデザインされた腰 台が両側にある．この廊下の出入口の形は図 22 に示す

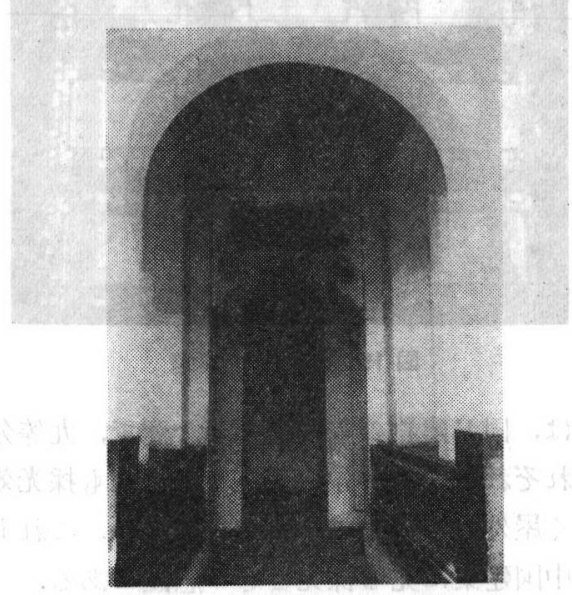

図 22 六角塔内廊下の唐草,

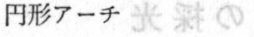

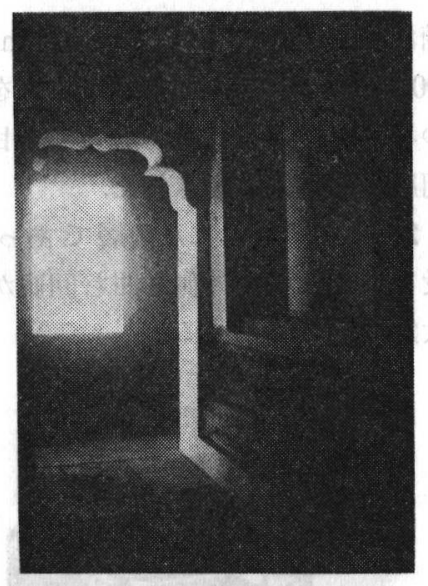

図 23 塔の採光と屋内意匠の 陰影

ように, 唐草や円孤状のアーチ式にデザインされている. そして図 23 に示すように, 長方形の外空から回廊を通し て採光された明からが，それぞれのアーチの形を光で浮き 上がらせ, 塔内に引き入れられ, 廊下両側の腰部の文様を も浮き彫りにし, 厳かに中央の塔室に光を引き入れる.こ こに, 1000年の歴史の中に中国だけでなく, インド, 中近 東の感覚の採光の意匠を見る思いがする.

\section{4. 霊隠寺, 大雄宝殿の採光の手法}

杭州, 霊隠寺は杭州最大の寺院で, 320 年, インドの僧 慧理によって開山され，またの名を雲林寺とも呼ばれ，た びたび修復され，現在の建物は清代に再建されたとされて いる.

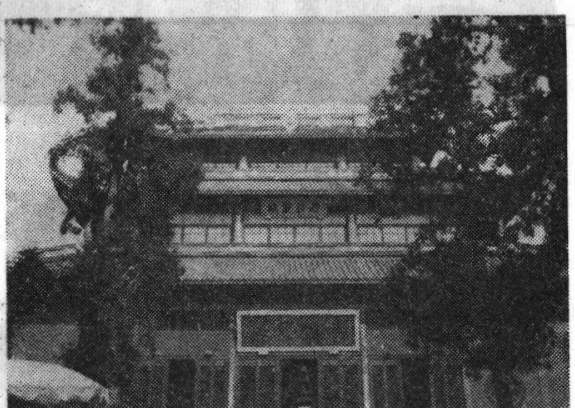

図24 大雄宝殿の全景

本殿の大雄宝殿には，高さ $19 \mathrm{~m}$ の黄金色の釈迦牟尼大 仏像が安置されている. 図 24 はその大雄宝殿の建物全景 である. 外観は 3 層の屋根構造で, それぞれ各層に採光空 を設けている。

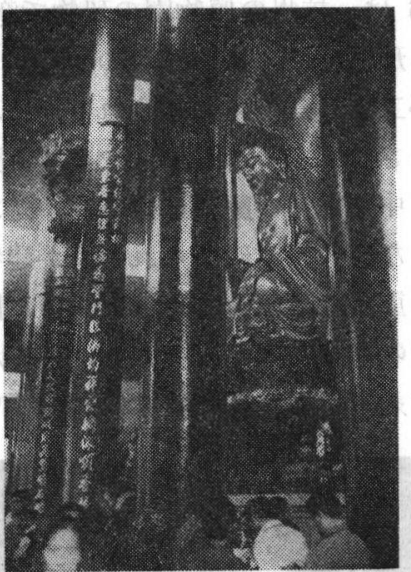

図 25 殿内棌迦大仏像の

$$
\text { 採光 }
$$

図 25 は殿内に安置された黄金色の釈迦大仏像である. この写真でもわかるように，各層の採光空からの光が上・ 中・下と 3 段からの採光が取られ，殿内はたいへん明かる く，大仏像にはどこからか人工の投光照明が行なわれてい るかのようにも見える.

この大雄宝殿の大仏像に対する採光について図解, 分析 を試みる。

図 26 の断面図に示すように, 殿高 $33.6 \mathrm{~m}$ の建物は 3 層の屋根で構成され，上・中段の側空と下段，1 階部の闌 間と出入扉, 四つの層の空, 扉により採光している. 仏座 を加えて像高 $24 \mathrm{~m}$ の仏像に対し，それぞれの高さに応じ 仏像に明かるく効果的な採光照明が行なわれている.

図でもわかるように, 仏像, 頭上の玉に対する照明, 仏 像の顔, 胸など, 効果的に光が当たっていることが写真で もわかる.

また，建物拝殿前の敷石が板状に広く敷きつめられて， 


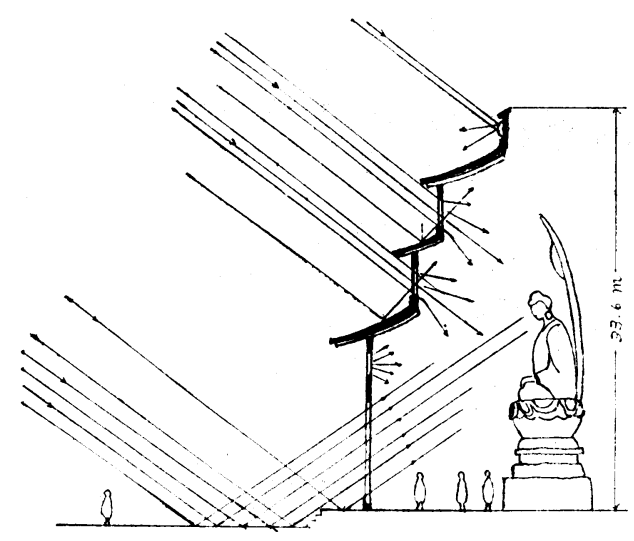

図 26 大婎宝殿の上仏像の採光分析図

特に，证面参道に沿って中央列の表面が白く仕上げられて いる（石の表面をとがった金盏でたたき出し，白い粗の闻 に仕上げてある)。これは，参抨者に対し滑らなくするた めの効果のほかに，太陽の直射光を柔らかく反射させ，堂: 内に引き入れる効果をねらっての工夫であると考察する。

日本庭園などでの白玉砂利の反射利用の採光手法と同じ效 果であり興味深い。

\section{5. あと がき}

以上，中国の古い建築に見る採光の手法やそれら意厉に ついて写真ならびに図で解説を加えたが，笽者が旅行前に
想像していた以上に，中国の古い建築物の採光の意匠は極 彩色で精巧で, 思いのほか明かるい世界であった。

中国の古い建築の空格子の文様に見るように，多くの種 類がデザインされ，ただ昼光の明かるさを利用するばかり でなく，それぞれの文様を通して光を変化させ，その建築 の外観や，室内の意厉に調和するように計画していること は心憎い。

また中国の庭眴の建築に見るように，相々な形の空孔の 形式, 願和固に胃る仆錦灯空, 額縁空の考方方など, 中国 の歴史と文化に加え, シルクロードを越えてインド，中近 東, ヨーロッパの影響も加わった中国人の意匠感覚に雄大 なロマンを感ずる.

本稿を執䇥するに当たり, 中国建築史編集委員会編「中 国建築の歴史」を通境できたことも非常に参考になり，樑 謝いたします。

なお，会員のかたがたに少しでも古い中国建築について の採光手法や，その意压について本稿が参考になれば幸い である。

\section{参 考 文 献}
(1)「中国建築の歴史」中国建築史編笨委员会編
(2)「中国旅行」日中平和観光
(3)「中国への旅」朝日新聞事業

（受付1983年 2 月 16 月）

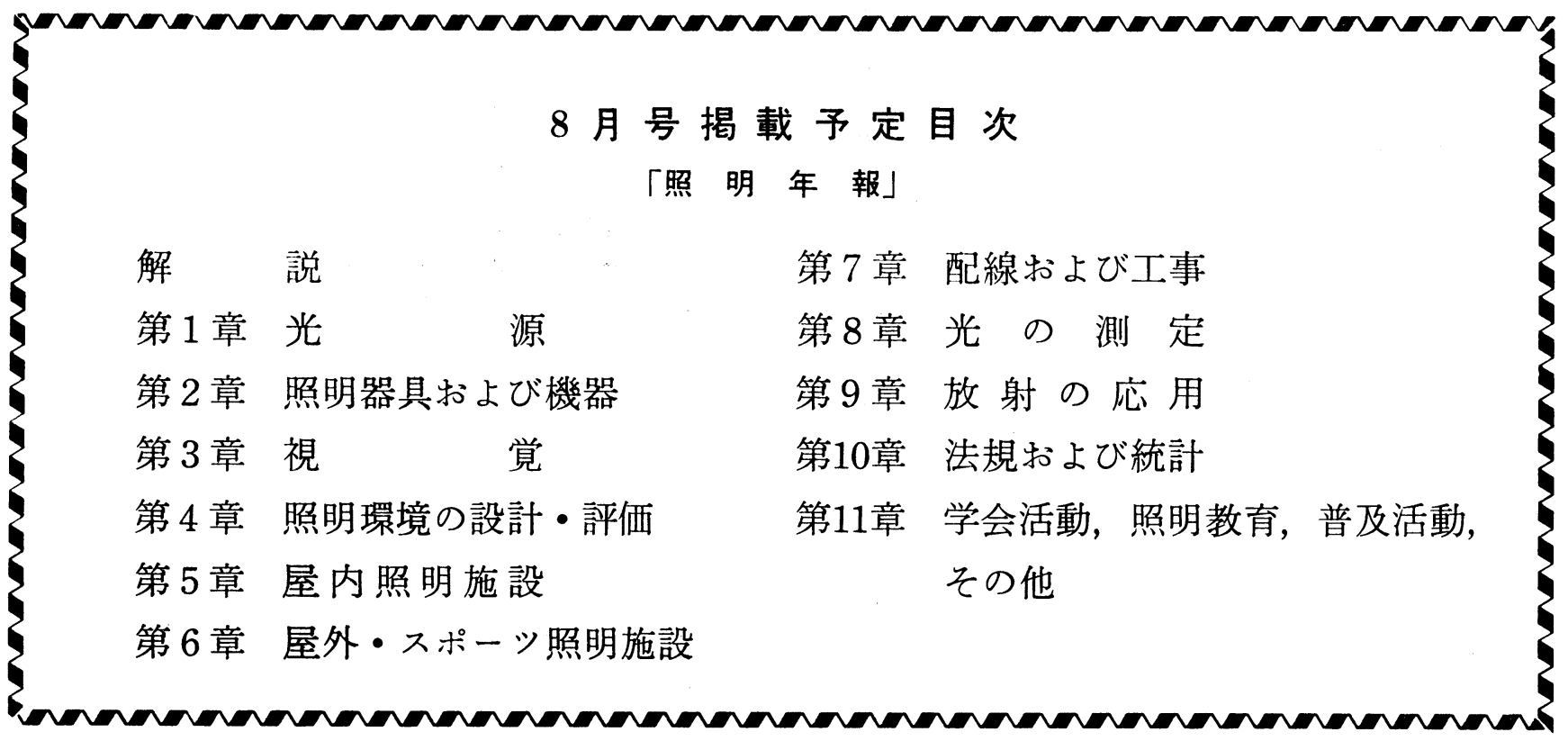

